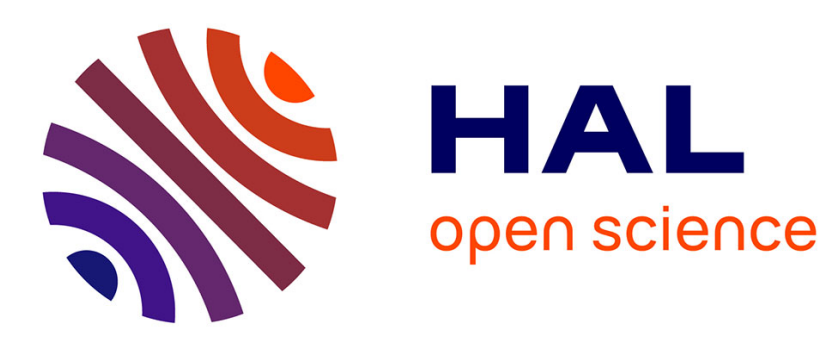

\title{
Wood elasticity of several Coffea canephora Pierre clones. A new trait to be included in selection schemes
}

Christian Cilas, Christophe Montagnon, Benoit Bertrand, Christophe Godin

\section{To cite this version:}

Christian Cilas, Christophe Montagnon, Benoit Bertrand, Christophe Godin. Wood elasticity of several Coffea canephora Pierre clones. A new trait to be included in selection schemes. Agronomie, 2000, 20 (4), pp.439-444. 10.1051/agro:2000140 . hal-00886051

\section{HAL Id: hal-00886051 https://hal.science/hal-00886051}

Submitted on 1 Jan 2000

HAL is a multi-disciplinary open access archive for the deposit and dissemination of scientific research documents, whether they are published or not. The documents may come from teaching and research institutions in France or abroad, or from public or private research centers.
L'archive ouverte pluridisciplinaire HAL, est destinée au dépôt et à la diffusion de documents scientifiques de niveau recherche, publiés ou non, émanant des établissements d'enseignement et de recherche français ou étrangers, des laboratoires publics ou privés. 


\title{
Wood elasticity of several Coffea canephora Pierre clones. A new trait to be included in selection schemes
}

\author{
Christian Cilas*, Christophe Montagnon, Benoit Bertrand, Christophe Godin \\ Collaboration between the Centre de Coopération International en Recherche Agronomique pour le Développement (CIRAD), \\ the Centre National de Recherche Agronomique de Côte d'Ivoire (CNRA) \\ and the Institut Togolais de Recherche Agronomique (ITRA).
}

CIRAD-CP, BP 5035, 34032 Montpellier Cedex, France

(Received 2 December 1999; accepted 21 March 2000)

\begin{abstract}
Genetic improvement of tree crops cultivated for their fruits or seeds does not usually take into account the physical properties of their wood. Yet, wood breakage in coffee trees during harvests or lodging are major defects in some cultivars. Such defects are linked to certain physical properties of the wood, such as elasticity, which is characterized by a parameter used in resistance testing of materials: the modulus of elasticity (MOE), or Young's modulus. The MOE of several coffee clones (Coffea canephora) was therefore evaluated in the Ivory Coast and in Togo. An estimation of broad sense heritability for the MOE gave a value of around 0.3 . The species can therefore be genetically improved for this parameter. The MOE could also be used to predict certain traits of agronomical interest. Moreover, it is necessary to estimate this parameter to model coffee tree architecture, notably with a view to establishing eco-physiological models. The measuring method is to be improved, so as to obtain more accurate estimations.
\end{abstract}

modulus of elasticity (MOE) / wood physics / heritability / Coffea canephora

Résumé - Élasticité du bois de plusieurs clones de Coffea canephora Pierre. Un nouveau caractère à considérer dans les schémas de sélection. Les propriétés physiques du bois ne sont généralement pas prises en compte dans l'amélioration génétique des espèces pérennes cultivées pour leurs fruits ou leurs graines. Pourtant, chez le caféier, la casse du bois durant les récoltes ou la verse sont des défauts majeurs de certains cultivars. Ces défauts sont liés à certaines propriétés physiques du bois comme l'élasticité, caractérisée par un paramètre utilisé en résistance des matériaux : le module d'élasticité ou module de Young. Le module d'élasticité de plusieurs clones de caféiers (Coffea canephora) a donc été évalué en Côte d'Ivoire et au Togo. L'estimation de l'héritabilité au sens large du module d'élasticité donne une valeur proche de 0.3 . Ce paramètre peut donc être amélioré par voie génétique. Le module d'élasticité pourrait également être utilisé comme prédicteur de certains caractères d'intérêt agronomique. Par ailleurs, l'estimation de ce paramètre est nécessaire pour la modélisation architecturale des caféiers, notamment dans la perspective d'établir des modèles éco-physiologiques. Des améliorations de la méthode de mesure sont envisagées pour obtenir des estimations plus précises du module d'élasticité.

module d'élasticité / physique du bois / héritabilité / Coffea canephora

* Correspondence and reprints

christian.cilas@cirad.fr 


\section{Introduction}

The physical characteristics of forest species have been studied for many years, notably to measure the quality of the timber produced [10-12, 18]. The genetic variability of some characteristics has been studied in different species with a view to improving the rheological properties of cultivated species $[2,9,19]$.

In tree crops cultivated for a purpose other than their wood, such as fruit trees, Hevea, or coffee, there have been very few studies dealing with the physical properties of their wood. Yet, those properties can be involved in phenomena that jeopardize the crop, such as wind damage in Hevea [3, 7, 16] or lodging in coffee [4]. The coffee tree is one of the scarce perennial plants susceptible to lodging, but there is a variability for that trait in the main two cultivated species: Coffea arabica L. and Coffea canephora Pierre [5]. Susceptibility to lodging primarily depends on the elasticity of the wood. Whilst lodging is often linked to an excessive flexibility in the wood, high rigidity can lead to breakage of the main stems or branches at harvest time. Optimum elasticity therefore needs to be sought to suit different cultivation practices.

The genetic variability of longitudinal elasticity in coffee tree wood was therefore studied on clones of the $C$. canephora species in the Ivory Coast and in Togo. Elasticity is conventionally characterized by measuring Young's modulus, or the modulus of elasticity (MOE). The heritability of this physical characteristic was estimated with a view to taking that trait into account in the genetic improvement of the species, either as a target trait (search for optimum MOE), or as a predictive trait for other traits of agronomical interest (yield, susceptibility to various pests and diseases).

\section{Materials and methods}

\subsection{Planting material}

The MOE was measured on 11 clones of the $C$. canephora species in Ivory Coast and Togo, clone 126 being common to both countries (Tab. I). These clones were a sample of the mixture of clones distributed in each country. Four to twelve trees per clone were sampled and one plagiotropic branch per tree was tested to assess the MOE. The sampled plagiotropic branches were situated in the middle part of the trees, between the fifteenth and the twentieth pairs of branches from the top.

\subsection{Modulus of Elasticity (MOE)}

Under the influence of outside forces, the molecular forces ensuring the cohesion of a wood sample resist against the corresponding potential distorsions. Such an influence therefore leads to deformation of the sample up to the point where an equilibrium is reached between the outside and internal forces. If the intensity of the outside forces causing deformation is gradually reduced, the solid partially or totally resumes its initial shape. The ability of a body to resume its initial external form once the outside force is removed is known as elasticity. A body is perfectly elastic if it totally recovers its initial form once such forces have been removed. In this study, coffee wood was considered to be a perfectly elastic material, which was a good approximation for low-intensity forces [10].

In a tension or compression test on perfectly elastic materials, there is a linear relation between the deformation produced and the outside forces exerted. This relation is known as Hooke's law.

Table I. List and repartition of the studied clones.

\begin{tabular}{lcccccccccccc}
\hline Clones & 119 & 202 & 305 & 588 & 126 & 107 & 149 & 181 & 182 & 200 & Ao3 \\
\hline $\begin{array}{l}\text { Ivory Coast } \\
\text { Togo }\end{array}$ & + & + & + & + & + & & & & & & & \\
\hline
\end{tabular}


For a uniform wood sample with a constant crosssection $S$ and length $L$, subject to a tensile force $F$ perpendicular to its cross-section, and resulting into an elongation $\Delta L$, Hooke's law is written as:

$$
\sigma=E \varepsilon
$$

where, $\sigma=F / S$ (the stress produced by the outside force $F$ ),

$\varepsilon=\Delta L / L$ (the relative displacement induced by $F$ ),

$E \quad$ is the MOE of the material, or Young's modulus.

For most materials such as wood, the MOE when subject to stretching is equal to its value when subject to bending, at least for a limited range of forces and deformations.

As forces of tension usually only induce small displacements, bending tests are often preferred. If a force $F$ is applied to the free end of an embedded bar (with an axial symmetry) perpendicular to its axis, it can be shown that the bending moment $M f(x)$ at distance $x$ from the embedding point is inversely proportional to the curvature radius $R(x)$ at that point:

$$
M f(x)=\frac{E I(x)}{R(x)}
$$

where $E$ is MOE for the material, and $I(x)$, the moment of inertia, is a geometrical characteristic of the cross-section of the wooden bar at point $x$.

Let us note $y(x)$, the ordinate of the bar's axis of symmetry after bending at point $x$. For slight displacements, the radius of curvature at point $x$ can be obtained by the inverse of the second derivative of $y(x)$. That makes it possible to obtain a differential equation describing the shape of the bar after bending (in the case of small displacements):

$$
\frac{d^{2} y(x)}{d x^{2}}=\frac{M f(x)}{E I(x)}
$$

i.e. by explicating the bending moment and inertia at point $x$ of a truncated cone test piece (for a cir- cular cross-section of diameter $D(x), I(x)=$ $\left.\pi D(x)^{4} / 64\right)$ :

$$
\frac{d^{2} y(x)}{d x^{2}}=\frac{64 F(L-x)}{E \pi D^{4}(1-B x)^{4}}
$$

where, $B=(D-d) / D L$.

Integration of this differential equation, for a bar with the geometry of a frustum, gives the following expression of $y(x)[4,5]$ :

$$
E=\frac{64 L^{3} \Delta F}{3 \pi D^{3} d \Delta f}=\frac{6.79 L^{3} \Delta F}{D^{3} d \Delta f}
$$

where, $L$ is the length of the branch,

$F$ is the weight applied to the free end,

$f$ is the displacement of the free end under force $\mathrm{F}$ (flexion),

$D$ is the branch diameter at the fixed end,

$d$ is the branch diameter at the free end, to which the force is applied.

\subsection{Measurement methods}

The MOE values were estimated by applying different bending forces to coffee tree branches [4]. The end of the branch with the largest diameter was fixed and weights were hung on the other end. Three different weights $(50 \mathrm{~g}, 100 \mathrm{~g}$ et $150 \mathrm{~g})$ were hung on the free ends and the displacement of those ends was measured. The diameters of the branch at both ends, along with the length, were measured to calculate the MOE of the wood. The MOE of each branch was estimated by linear regression, from equation (2), with each force applied causing displacement of the free end. These tests were carried out on fresh lignified wood, which is more elastic than dry wood, obtained from branches taken from mature coffee trees. MOE values were expressed in MPa (megapascals), i.e. in Newtons per $\mathrm{mm}^{2}$.

\subsection{Data analysis}

One-way analysis of variance by country were carried out, along with Newman and Keuls tests, to 
classify the MOE means for the different clones. A nested model was used to analyse the whole data; in this case the two factors were "country" and "clone(country)".

"Clone" and "error" variances were firstly estimated by country. Then, "Clone" and "error" variances were estimated in a two-way non-orthogonal ANOVA with a nested model [17], the "country" factor being considered with fixed effects and the "clone" factor with random effects. In this case, the clone 126 in Togo data set was discarded. Broad sense heritabilities of the MOE were then estimated by country and for both countries. The estimation was given by the ratio of genetic variance ("clone" variance) and phenotypic variance (total variance of the sample) [8]. Standard deviations of estimates of heritabilities were computed using the robust Jackknife method [13].

\section{Results}

Distribution of the MOE values measured on the different clones were graphically compared (Fig. 1) using the box plot graphs and dispersion parameters of the normal law [14]. Their seemed to be a difference in variance between clones, though it was not significant at the 5\% level as checked by the Bartlett test $\left(\chi^{2}=12.63\right.$ with $\left.\mathrm{p}=0.245\right)$.

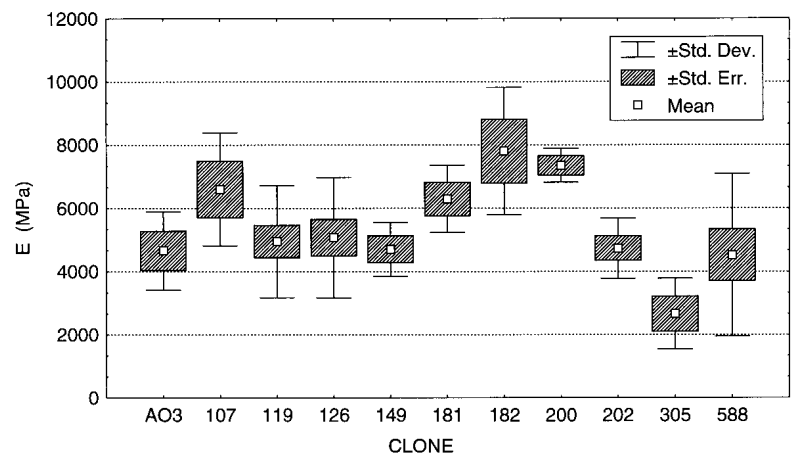

Figure 1. Box plot of MOE values per clone.
Table II. One-way analysis of variance of the MOE.

\begin{tabular}{lccc}
\hline Source of variation & df & observed F & Probability \\
\hline Clone (Ivory Coast) & 4 & 3.61 & 0.017 \\
Clone (Togo) & 7 & 2.67 & 0.045 \\
\hline
\end{tabular}

Table III. Comparison of clonal means for MOE in each country (Newman-Keuls tests at 5\% level).

\begin{tabular}{lcc}
\hline Clone & $\begin{array}{c}\text { MOE mean (Mpa) } \\
\text { in Ivory Coast }\end{array}$ & $\begin{array}{c}\text { MOE mean (Mpa) } \\
\text { in Togo }\end{array}$ \\
\hline 182 & & $7807 \mathrm{a}$ \\
200 & & $7355 \mathrm{a} \mathrm{b}$ \\
107 & & $6601 \mathrm{a} \mathrm{b}$ \\
181 & & $6296 \mathrm{a} \mathrm{b}$ \\
119 & $5855 \mathrm{a}$ & \\
588 & $5443 \mathrm{a}$ & $6202 \mathrm{a} \mathrm{b}$ \\
126 & $4843 \mathrm{a}$ & $4701 \mathrm{~b}$ \\
202 & $4736 \mathrm{a}$ & $4660 \mathrm{~b}$ \\
149 & & \\
Ao3 & & \\
305 & $2659 \mathrm{~b}$ & \\
\hline
\end{tabular}

The clones were compared by a one-way analysis of variance for each country (Tab. II). The clone effects were significant at the 5\% level in both places. In each country, the Newman and Keuls test revealed two homogeneous groups (Tab. III). For both countries, the heritability was around 0.3 , but not significantly different from 0 in Togo (Tab. V).

The nested model was then applied (Tab. IV); it revealed a great difference of the mean values between the two countries. The mean of MOE from Togo was higher than from Ivory Coast $(6188 \mathrm{Mpa}>4955 \mathrm{Mpa})$. The diameters of the large end of the branches of Togo were significantly smaller $(5.5 \mathrm{~mm}<6.8 \mathrm{~mm})$, and these branches were certainly drier. Heritability of the MOE was estimated with this model in order to use the information about the complete set of eleven clones. In this case, we used 5 clones from Ivory Coast and 6 clones from Togo (clone 126 was deleted in this 
Table IV. Nested model analysis for the MOE.

\begin{tabular}{lccc}
\hline Source of variation & df & observed F & Probability \\
\hline Country & 1 & 16.01 & 0.0002 \\
Clone (country) & 10 & 3.06 & 0.0045 \\
\hline
\end{tabular}

Table V. Estimates of broad sense heritability of the MOE and standard deviation.

\begin{tabular}{lcc}
\hline & $\begin{array}{c}\text { Broad sense } \\
\text { heritability }\end{array}$ & $\begin{array}{c}\text { Standard } \\
\text { deviation }\end{array}$ \\
\hline Ivory Coast & 0.288 & 0.170 \\
Togo & 0.303 & 0.205 \\
Both countries (nested model) & 0.335 & 0.125 \\
\hline
\end{tabular}

last country). The estimated heritability was greater than the ones estimated for each country. This broad sense heritability was significantly greater than 0 (Tab. V). This estimation of broad sense heritability for the MOE $\left(\hat{\mathrm{h}}^{2}=0.335\right)$ indicated that a genetic progress could be achieved for this trait in the $C$. canephora species.

MOE could also be correlated to agronomical traits. For example, yield data of the four first years of production were available for four clones in Ivory Coast. These data came from nine plots representative of the coffee culture area in Ivory Coast [15]. Yield per year as a function of MOE was presented for Ivory Coast (Fig. 2), as well as for Togo (Fig. 3). In Togo, yield data were obtained in two plots for four years. In both countries low MOE was linked to low yield. Nevertheless, few clones were used to study this relation and this must be further investigated.

\section{Discussion and conclusion}

The MOE has a sufficient genetic variability within the $C$. canephora species; this characteristic of coffee tree wood can therefore be improved genetically. The estimated values were around the

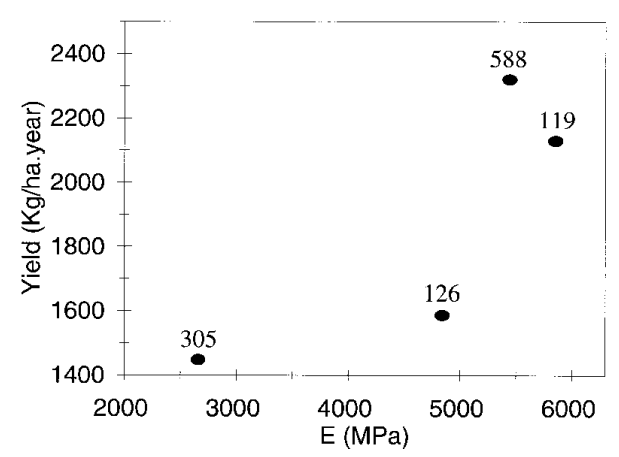

Figure 2. Relation between yield and MOE means per clone (for four clones in Ivory Coast).

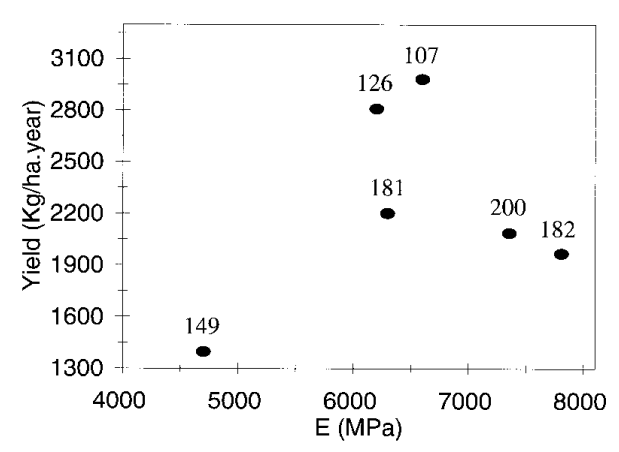

Figure 3. Relation between yield and MOE means per clone (for six clones in Togo).

same magnitude as those obtained previously [4, 5]. The broad sense heritability of the MOE is quite high, and the additive and dominance genetic variances will soon be estimated from different mating designs within the C. canephora species.

Although the measurement method employed is easy to use, it did reveal significant differences between the studied clones. However, the method used to estimate the MOE can be improved and new methods will be soon tested [1].

Genetic improvement of MOE in coffee tree wood should make it possible to obtain trees less susceptible to lodging and breakage. In order to do that, it would be necessary to determine the optimum elasticity range. This character can also be considered in relation to other architectural and agronomical characteristics, in order to estimate its 
impact on traits of interest. Lastly, knowledge of this parameter is required for developing synthetic images and for ecophysiological studies [6].

Acknowledgements: The authors acknowledge Dr. Henri Baillères from CIRAD-Forêt for kindly reviewing the manuscript and Peter Biggins for the translation.

\section{References}

[1] Baillères H., Calchera G., Demay L., Fouquet D., Vernay M., Classement des bois guyanais de structure. Comparaison de trois techniques non-destructives : visuelle, ultrasonore et analyse modale, in: ARBOLOR $4^{\mathrm{e}}$ Colloque sciences et industries du bois, Nancy, 1996, pp. 369-376.

[2] Bouvet J.M., Baillères H., Expression of some growth and wood property traits among Eucalyptus urophylla grandis clones in Congo, in: Vigneron P., Gérard J., Bouvet J.M., Baillères H., Verhaegen D., Kremer A. (Eds.); CIRAD-Forêt - Eucalyptus plantations: improving fibre yield and quality, CRC IUFRO, 1995, pp. 1-6.

[3] Clément Demange A., Chapuset T., Legnaté H., Costes E., Doumbia A., Obouayeba S., Nicolas D., Wind damage: the possibilities of an integrated research for improving the prevention of risks and the resistance of clones in the rubber tree, in: IRRDB - Symposium on physiological and molecular aspects of the breeding of Hevea brasiliensis, Penang, 1996, pp. 182-199.

[4] De Reffye Ph., Modélisation et simulation de la verse du caféier à l'aide de la théorie de la résistance des matériaux, Café Cacao Thé 20 (1976) 251-272.

[5] De Reffye Ph., Amélioration de la résistance à la verse du caféier à l'aide de la théorie de la résistance des matériaux, in: 8th International Scientific Colloquium on Coffee, ASIC, Côte d'Ivoire, 1977, pp. 439-445.

[6] De Reffye Ph., Blaise F., Houllier F., Modelling plant growth and architecture: some recent advances and applications to agronomy and forestry, Acta Horticulturae 456 (1998) 105-116.

[7] Dinouard P., De Reffye P., Jaeger M., Modélisation et simulation de l'architecture de l'hévéa, Rev. Gén. Caoutch. Plast. 64 (1987) 53-55.

[8] Falconer D.S., Introduction à la génétique quantitative, Masson, 1974, 284 p.

[9] Gérard J., Variations radiales de densité et de module d'élasticité longitudinal chez les Eucalyptus clonaux du Congo : premiers résultats, in: USTL Architecture, structure, mécanique de l'arbre (6), 1993, pp. 164-173.

[10] Guitard D., El Amri F., Modèles prévisionnels de comportement élastique tridimensionnel pour les bois feuillus et les bois résineux, Ann. Sci. For. 44 (1987) 335-358.

[11] Koizumi A., Ueda K., Estimation of the mechanical properties of standing trees by bending test 1 - Test method to measure the stiffness of a tree trunk, Mokuzai Gakkaishi 9 (1986) 669-676.

[12] Kollmann F.F.P., Côté W.A, Principles of wood science. I - Solid wood, Springer-Verlag, 1968, 592 p.

[13] Lebart L., Morineau A., Fénelon J.P., Traitements des données statistiques, Dunod, Paris, 1979, $510 \mathrm{p}$.

[14] McGill R., Tukey J.W., Larsen W.A. Variations of box plots, Am. Stat. 32 (1978) 12-16.

[15] Montagnon C., Cilas C., Leroy T., Yapo A., Charmetant P., Genotype-location interactions for Coffea canephora yield in Ivory Coast, Agronomie 20 (2000) 101-109.

[16] Nicolas D., Comportement de quelques clones d'hévea (Hevea brasiliensis) dans le Sud-est de la Côte d'Ivoire, Rev. Gén. Caoutch. Plast. 56 (1979) 175-181.

[17] Searle S.R., Linear models, Wiley, New York, 1971, 532 p.

[18] Zobel B.J., van Buijtenen J.P., Wood variation, Springer-Verlag, 1989, 502 p.

[19] Zobel B.J., Jett J.B., Genetics of wood production, Springer-Verlag, 1995, 526 p. 